\title{
Corrigendum
}

\section{Association of BMI and nutritional habits with hypertension in the adult population of Croatia - Corrigendum}

\author{
Ana Ivičević Uhernik, Marijan Erceg and Sanja Musić Milanovic
}

doi:10.1017/S1368980008001997, Published online by Cambridge University Press 15 April 2008

First published online 3 September 2010

In the third paragraph of the Sample section on page 98,

instead of:

Data were collected by public health nurses from April to June 2003. They took anthropometric measures such as height, weight and blood pressure, and interviewed respondents.

it should read:

Data were collected by public health nurses from April to June 2003. They measured blood pressure and interviewed respondents. Height and weight were self-reported by respondents.

This mistake occurred due to incorrect information published in Croatian Adult Health Survey. Users' guide. In: 2003 Croatian Adult Health Survey Master Microdata File Documentation. Republic of Croatia Ministry of Health. Health Systems Project IBRD Loan 4513-0 HR. Zagreb; 2003.

\section{Reference}

Uhernik AI, Erceg M \& Milanovic SM (2009) Association of BMI and nutritional habits with hypertension in the adult population of Croatia. Public Health Nutr 12, 97-104. 